\title{
Aplikasi Android Lukisan Wayang Kamasan Menggunakan Qr Code Sebagai Media Promosi Interaktif ( Studi Kasus: Startup Way'K)
}

\author{
Gede Wira Astawa ${ }^{1)}$, I Gusti Lanang Agung Raditya Putra ${ }^{2)}$, I Gede Putu Krisna Juliharta ${ }^{3)}$ \\ Program Studi Sistem Informasi ${ }^{12) 33}$, \\ Sekolah Tinggi Manajemen Informatika dan Komputer (STMIK) Primakara ${ }^{12) 3)}$, \\ wiraastawa@gmail.com ${ }^{1)}$, la.raditya27@gmail.com ${ }^{2)}$, lemberto@gmail.com ${ }^{3)}$
}

\begin{abstract}
ABSTRAK
Lukisan Wayang Kamasan merupakan salah satu kerajinan yang merupakan warisan budaya Bali. Salah satu startup yaitu Way'K menginovasikan Lukisan Wayang Kamasan menjadi produk modern seperti lukisan jam dinding, lukisan lampu LED, dan souvenir berupa plakat. Namun hal tersebut belum cukup untuk meningkatkan daya jual dari seni lukis wayang kamasan karena berdasarkan hasil wawancara terhadap owner startup Way'K wisatawan kurang tertarik membeli karena wisatawan tidak mengetahui dari makna dan cerita yang terdapat dalam lukisan tersebut, selain itu promosi dan penjualan masih dilakukan secara konvensional mengingat perkembangan zaman memasuki era digital. Maka dari itu penulis membuat suatu aplikasi seni lukis Wayang Kamasan berbasis Android yang dapat menampilkan cerita lukisan melalui kode $Q R$ yang dipindai pada lukisan serta terdapat fitur informasi dan pembelian produk secara online melalui aplikasi. Pada pembuatan aplikasi menggunakan metode pendekatan software waterfall dan menggunakan pemodelan Use Case serta Class Diagram dalam perancangan aplikasi. Aplikasi dibangun menggunakan framework React Native dan framework Laravel dan diuji menggunakan metode blackbox testing dan aplikasi telah berhasil dirancang bangun dan berhasil di uji coba dengan hasil sesuai dengan yang diharapkan. Untuk mengetahui tingkat kemudahan penggunaan sistem dilakukan dengan metode Usability testing dan didapatkan hasil sangat baik.
\end{abstract}

Kata Kunci : Lukisan Wayang Kamasan, Aplikasi Android, Kode QR

\section{PENDAHULUAN}

Bali merupakan salah satu provinsi di Indonesia sebagai penyumbang devisa tertinggi dari sektor pariwisata, dihimpun dari data Badan Pusat Statistik Provinsi Bali tercatat sebanyak 5.697.739 wisatawan telah berkunjung ke Bali pada tahun 2017 [1]. Menurut Utama dan Mahadewi faktor daya tarik wisatawan ke Bali adalah untuk melihat kebudayaan unik khas Pulau Bali [2]. Lukisan Wayang Kamasan merupakan salah satu kerajinan yang juga merupakan warisan budaya Bali. Disebut lukisan Wayang Kamasan, karena kerajinan ini hanya dapat dijumpai di desa Kamasan, Kabupaten Klungkung, Bali. Lukisan Wayang Kamasan memiliki keunikan tersendiri dilihat dari ciri-ciri lukisan yang sangat khas yaitu tokoh dalam Lukisan Wayang Kamasan diambil dari tokoh dan cerita pewayangan seperti cerita Ramayana yang terdapat tokoh Rama, Sintha, Rahwana dan lain lain dan cerita lainya seperti kisah perang saudara Mahabaratha yang terdapat tokoh Yudisthira, Arjuna, Bima dan lainnya. Secara visual Lukisan Wayang Kamasan memiliki estetika yang sangat artistik, didalamnya terkandung cerita dan nilai-nilai filsafat yang bersifat simbolik yang sering digunakan sebagai pencerahan dan bayangan dalam kehidupan manusia di dunia maupun di akhirat [3]. Startup Way'K merupakan sebuah UKM (Usaha Kecil Menengah) yang digagas oleh beberapa mahasiswa dan dosen dari kampus STMIK Primakara, Way'K membuat inovasi Lukisan Wayang Kamasan menjadi lebih modern seperti lukisan jam dinding, lukisan lampu LED, dan souvenir berupa plakat guna meningkatkan nilai tambah keunikan dan nilai jual dari Lukisan Wayang Kamasan tanpa menghilangkan kearifannya.

Berdasarkan hasil wawancara dengan owner startup Way'K inovasi yang dilakukan startup 
Way'k belumlah cukup untuk meningkatkan daya tarik dan eksistensi dari Lukisan Wayang Kamasan karena wisatawan kurang tertarik dikarenakan wisatawan tidak mengetahui secara jelas apa itu sebenarnya Lukisan Wayang Kamasan, cerita dan makna dari lukisan tersebut, serta proses promosi produk yang dilakukan oleh startup Way'K masih dilakukan secara konvensional. Maka dari itu penulis akan mengkolaborasikan produk lukisan Wayang Kamasan dari startup Way'K dengan teknologi $Q R$ Code yang ada pada aplikasi Android dimana penulis akan merancang bangun sebuah aplikasi mobile berbasis sistem operasi Android yang kedepanya aplikasi ini dapat memberi nilai tambah pada produk Way'K. Aplikasi ini akan berisi fitur yang memanfaatkan teknologi $Q R$ Code (Quick Resnponse Code) dimana aplikasi ini memungkinkan pengguna mengetahui cerita dan sejarah dibalik Lukisan Wayang Kamasan dengan cara memindai $Q R$ Code yang ada pada lukisan yang kemudian akan menampilkan cerita pada lukisan Wayang Kamasan tersebut serta menampilkan berbagai informasi mengenai startup Way'K.

\section{TINJAUAN PUSTAKA}

\subsection{Penelitian Terkait}

Terdapat beberapa penelitian sebelumnya yang menggunakan aplikasi Android dan $Q R$ Code sebagai media penyampaian informasi. penelitian yang berjudul Pengembangan $Q R$ Code Scanner Berbais Android Untuk Sistem Informasi Museum Sonobudoyo Yogyakarta dimana penelitian ini membahas tentang Aplikasi Android yang menerapkan $Q R$ Code sebagai media penyampaian informasi kepada pengunjung mengenai barang yang ada di museum Sonobudoyo. Hasil dari penelitian ini adalah sebuah aplikasi Android yang berguna menyampaikan informasi mengenai barang yang ada di museum Sunobudoyo melalui kode $Q R$ yang di scan pada barang museum [4].

Penelitian lainya yang berkaitan dengan penggunaan aplikasi Android dengan $Q R$ Code sebagai media penyampaian informasi dan promosi dalam penelitian yang berjudul Penggunaan $Q R$ Code Sarana Penyampaian
Promosi Dan Informasi Kebun Binatang Berbasis Android dalam penelitian ini membahas tentang pemanfaatan $Q R$ code dalam aplikasi Android untuk penyampaian informasi mengenai satwa yang ada pada kebun binatang dan hasilnya Penggunaan aplikasi $Q R$ code ini memberikan kemudahan bagi pengunjung kebun binatang karena akses informasi dan promosi jauh lebih efektif dan fleksibel bagi pengunjung, karena tidak perlu lagi akses beberapa kali untuk mendapatkan informasi dan promosi [5].

Perbedaan dengan penelitian sebelumnya adalah pada penelitian ini ada pada arsitektur sistem dimana dalam penelitian ini terdapat dua platform yang digunakan dalam pembuatan sistem yaitu admin yang menggunakan platform website untuk menambah, menghapus dan meng-update data dan platform Android untuk menampilkan informasi lukisan melalui kode $Q R$ yang di scan pada lukisan. arsitektur sistem seperti di atas memungkinkan data bersifat dinamis dapat ditambah dihapus dan diubah. selain itu pada penelitian ini menggunakan framework Laravel pada bagian website dan framework React Native pada bagian aplikasi Android.

\subsection{QR Code}

Quick Response Code atau lebih sering kita sebut $Q R$ Code merupakan gambar digital dalam bentuk (2D) dua dimensi yang dapat dengan mudah dipindai oleh kamera smartphone dimana saat kode $Q R$ di scan oleh smartphone maka smartphone akan dengan cepat menampilkan data yang terdapat dalam $Q R$ Code tersebut [6]. $Q R$ Code memiliki tingkat popularitas lebih tinggi daripada teknologi pendahulunya yaitu Barcode dimana $Q R$ Code memiliki banyak kelebihan seperti kapasitas data yang dimuat dalam kode dapat lebih banyak, optimalisasi ukuran, dan dapat dikombinasi dengan gambar, hal tersebut membuat $Q R$ Code dapat diimplementasikan dalam banyak hal seperti untuk pengkodean sebuah informasi kontak, link dll [7].

\subsection{Laravel}

Laravel merupakan sebuah kerangka kerja atau sering kita sebut sebagai framework dimana berbasis bahasa pemrograman PHP. 
Laravel menerapkan metode MVC (Model View Controller) dalam kerangka kerjanya. Laravel memiliki kinerja lebih cepat dalam memuat data dibandingkan dengan PHP native dan framework lainnya seperti codeigniter [8].

\subsection{React Native}

React Native adalah kerangka kerja atau framework yang merupakan pengembangan dari framework React.Js. React Native berfokus pada pengembangan aplikasi mobile. saat pertama kali diluncurkan React Native hanya dapat digunakan untuk mengembangkan aplikasi berbasis iOS namun saat ini React Native sudah dapat digunakan untuk mengembangkan aplikasi berbasis Android dan menjadikan framework React Native sebagai framework yang bersifat hybrid karena hanya dengan menulis satu kali kode program dapat langsung diimplementasikan pada iOS dan Android [9].

\section{METODOLOGI PENELITIAN}

Metode yang digunakan dalam penelitian ini adalah metode waterfall yang merupakan metode pengembangan perangkat lunak yang terdiri dari communication, planning, modeling, construction dan deployment [10] seperti pada gambar 3.1.

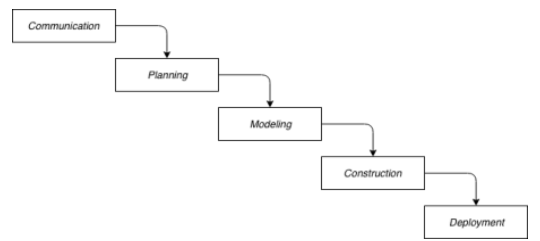

Gambar 1. Metode Waterfall

Tahapan pertama adalah dengan melakukan pengamatan mengenai proses promosi, selanjutnya dilakukan wawancara kepada owner startup Way' $\mathrm{K}$ mengenai perencanaan aplikasi yang ingin dibuat, serta mengumpulkan data berupa gambar lukisan Wayang Kamasan dan naskah cerita dan makna dari lukisan tersebut. tahapan berikutnya adalah pemodelan aplikasi dimana akan digambarkan dalam model use case diagram. Setelah itu dilakukan perancangan aplikasi yang hasilnya adalah sebuah perancangan dalam bentuk class diagram dan.
Pada tahapan implementasi adalah menerjemahkan hasil perancangan ke dalam kode program yang menggunakan framework Laravel pada bagian web admin dan framework React Native pada aplikasi Android. dan pada tahap pengujian akan digunakan metode blackbox testing dan menggunakan metode Usability Testing. responden yang dirujuk dalam pengujian adalah owner startup Way'K dan calon konsumen, pengujian System Usability Test dilakukan untuk mendapat masukan dari calon konsumen dan owner dengan cara memberikan kuesioner sedangkan pengujian blackbox testing digunakan untuk mengetahui kinerja aplikasi apakah sudah sesuai atau belum.

\subsection{Perancangan Element Sistem}

Pada bagian elemen input terdapat beberapa inputan yang akan digunakan dalam sistem yaitu username dan password yang digunakan untuk login pada web admin. Inputan lainya adalah data cerita, data produk, data kategori, dan data pelukis, sedangkan inputan pada bagian aplikasi android adalah $Q R$ Code dimana $Q R$ Code memuat sebuah id yang dikirim menuju API web admin dan mengambil data pada database sesuai $i d$ cerita yang di scan pada kode $Q R$ yang ada pada lukisan. Pada elemen proses terdapat beberapa data yang diproses yang akan menghasilkan output adapun data yang diproses adalah data cerita, data produk, data kategori, dan data pelukis. Pada elemen output sistem akan menghasilkan informasi kepada pengguna aplikasi, adapun informasi yang dihasilkan adalah info cerita, info produk, info pelukis. Perancangan elemen sistem secara lengkap dapat dilihat pada gambar 2 .

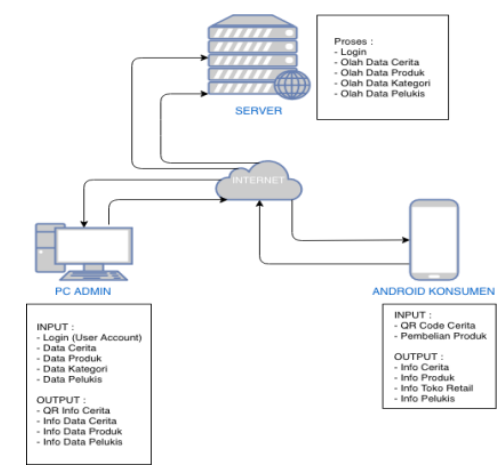

Gambar 2. Rancangan Elemen Sistem 


\subsection{Use Case Diagram}

Pada use case di bawah dapat dilihat bahwa Rancang sistem disini terdapat 2 aktor yaitu, Konsumen dan admin. Konsumen dapat melihat informasi cerita wayang, informasi produk, informasi pelukis dan informasi pada aplikasi Android. Sedangkan admin dapat mengelola data cerita, data produk, data pelukis serta dapat menambahkan ataupun mengurangi data yang ada dalam sistem tersebut. Use Case Diagram dapat dilihat pada gambar 3.

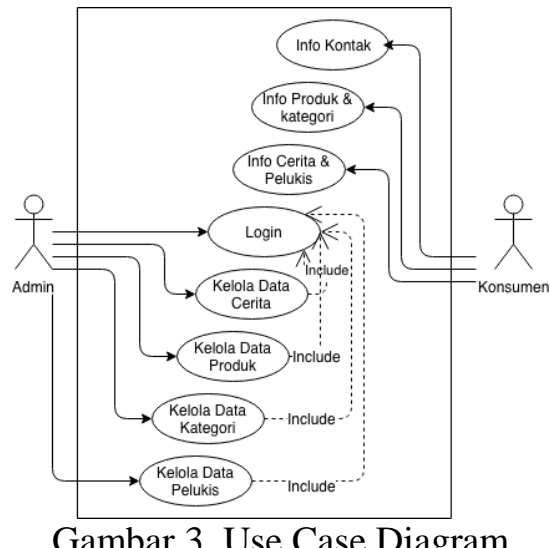

Gambar 3. Use Case Diagram

\subsection{Class Diagram}

Class diagram pada sistem ini terdiri dari 6 class, yaitu class User, Cerita, Produk, Kategori, Toko dan Pelukis. Class Diagram dapat dilihat pada Gambar 4.

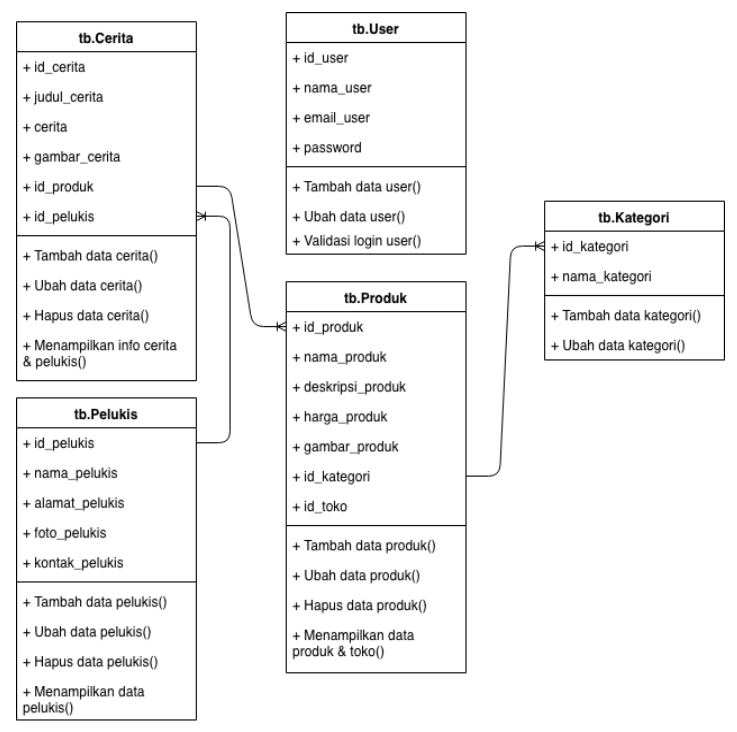

Gambar 4. Class Diagram

\section{HASIL DAN PEMBAHASAN}

Hasil dari perancangan sebelumnya menghasilkan aplikasi Android dan website admin: (1) Aplikasi Android berfungsi untuk memindai kode $Q R$ yang ada pada lukisan wayang kamasan dan menampilkan cerita dari lukisan tersebut, selain itu konsumen juga dapat menggunakan aplikasi untuk melihat dan membeli produk lukisan Wayang Kamasan dari Way'K, pada halaman utama terdapat halaman Scan $Q R$ yang dapat menampilkan cerita dari lukisan, $Q R$ yang dapat dipindai hanya kode $Q R$ yang terdapat pada lukisan Wayang Kamasan produk Way'K dan data yang dimuat dalam kode $Q R$ tersebut adalah sebuah id yang di request oleh aplikasi menuju web API yang kemudian mengakses database yang dapat dilihat pada gambar 5.

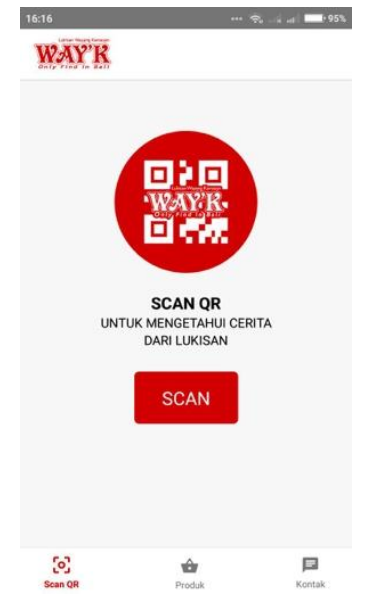

Gambar 5. Menu Scan $Q R$

Saat pengguna menekan tombol scan maka akan membuka pemindai $Q R$ untuk memindai kode $Q R$ yang ada pada lukisan wayang seperti terlihat pada gambar 6 .

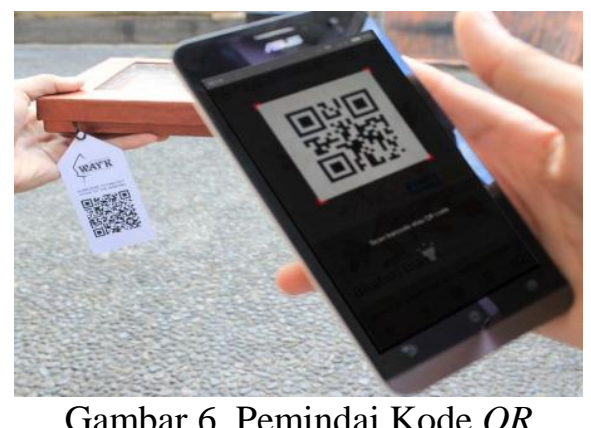

Gambar 6. Pemindai Kode $Q R$ 
Saat kode $Q R$ pada lukisan berhasil dipindai maka aplikasi akan menampilkan cerita dari lukisan yang dipindai kode $Q R$ nya seperti pada gambar 7.

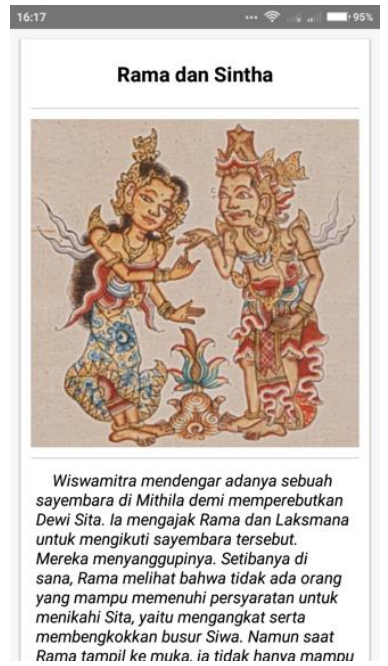

Gambar 7. Menampilkan Cerita Lukisan

Menu lainnya yang terdapat pada aplikasi adalah menu produk dimana konsumen dapat melihat produk lengkap dengan gambar, kategori dan harganya, selain itu konsumen dapat membeli produk langsung secara online seperti gambar 8 .

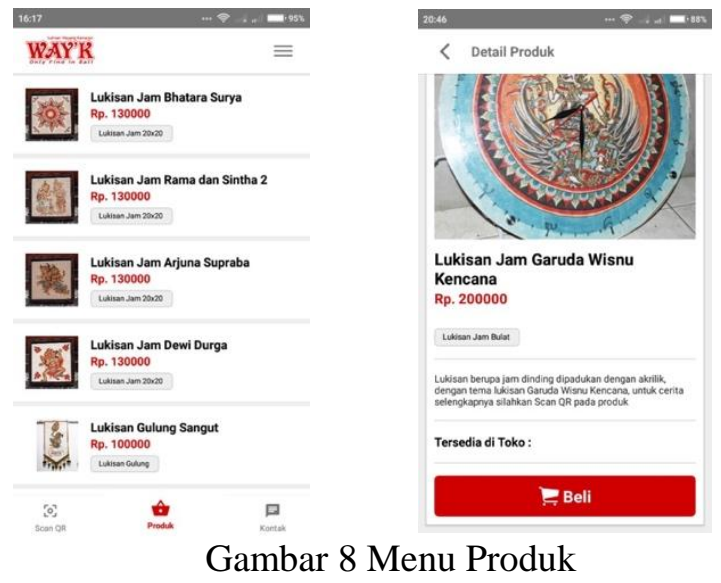

(2) Pada bagian admin berfungsi untuk menginput, mengubah dan menghapus data seperti data cerita, data produk dan lainnya, web admin dapat diakses setelah admin melakukan proses login seperti gambar 9 .

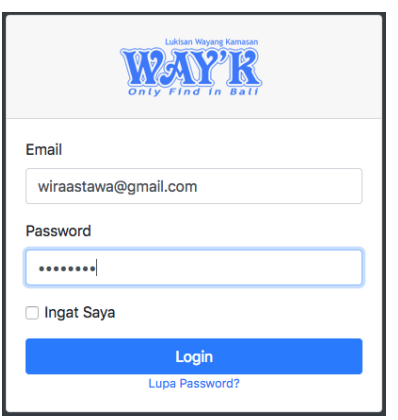

Gambar 9. Tampilan Login Web Admin

Setelah admin melakukan login maka admin dapat mengakses dashboard web admin yang menu utama terdapat beberapa tampilan informasi mengenai data yang tersimpan seperti gambar 10.

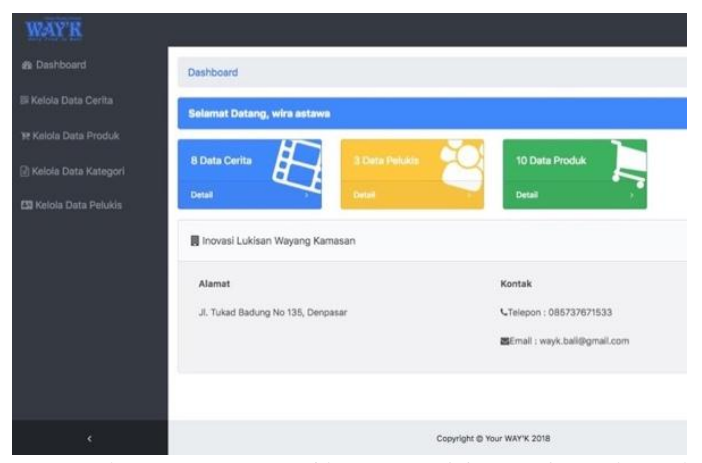

Gambar 10. Tampilan Dashboard Web Admin

Menu kelola data cerita merupakan menu yang diperuntukan menginput, mengubah dan menghapus data dari cerita untuk lukisan Wayang Kamasan, dalam menu tersebut admin dapat membuat $Q R$ secara langsung pada menu kelola data cerita menu kelola data cerita dapat dilihat pada gambar 11 .

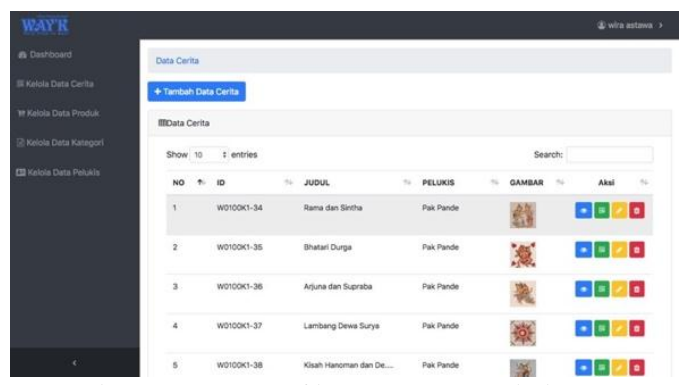

Gambar 11. Tampilan Menu Kelola Data Cerita 


\subsection{Pengujian Sistem}

pengujian sistem yang dilakukan pada penelitian ini adalah menggunakan metode blackbox testing, pengujian dilakukan dengan cara membandingkan data inputan pada sistem. pengujian dilakukan dengan dua kondisi data inputan yaitu data lengkap dan data tidak lengkap.

\subsubsection{Blackbox Testing}

Hasil pengujian menggunakan metode blackbox testing terdapat 2 inputan yang diuji yaitu pada web admin pada bagian form inputan cerita dan pada aplikasi Android pada bagian inputan scan $Q R$ code. hasil pengujian pada web admin dapat dilihat pada tabel 4.1. sedangkan pengujian aplikasi Android dapat dilihat pada tabel 4.2.

Tabel 1. Hasil Pengujian Input Cerita Web Admin

\begin{tabular}{ll}
\hline Kasus Hasil Pengujian (Sukses) \\
\hline Data & Judul Cerita = Rama dan \\
Inputan & Sintha \\
& Gambar = RamaSintha.Jpeg \\
& Cerita = Cerita Rama dan \\
& Sintha \\
Hasil yang & Ketika diklik tombol \\
diharapkan & simpan data akan disimpan \\
& ke database dan terdapat \\
& feedback data berhasil \\
disimpan.
\end{tabular}

Tabel 2 Pengujian Scan QR Aplikasi Android

\begin{tabular}{|c|c|}
\hline \multicolumn{2}{|c|}{ Kasus Hasil Pengujian (Sukses) } \\
\hline Data & Scan $Q R=Q R$ Code pada \\
\hline Inpl & lukisan wayang kamasan \\
\hline Has & Ketika $Q R$ code pada \\
\hline $\operatorname{dih}$ & $\begin{array}{l}\text { lukisan wayang kamasan di } \\
\text { scan menggunakan aplikasi } \\
\text { maka aplikasi akan } \\
\text { menampilkan cerita dari } \\
\text { lukisan tersebut }\end{array}$ \\
\hline Penga & $\begin{array}{l}\text { nenampilkan data } \\
\text { ai dengan lukisan }\end{array}$ \\
\hline Hasil & Sesuai \\
\hline \multicolumn{2}{|c|}{ Kasus dan hasil pengujian (alternatif) } \\
\hline Data & Scan $Q R=Q R \mathrm{c}$ \\
\hline Mas & istem \\
\hline $\begin{array}{l}\text { Hasil yang } \\
\text { diharapkan }\end{array}$ & $\begin{array}{l}\text { Akan tampil notifikasi, } Q R \\
\text { code tidak sesuai, cerita } \\
\text { tidak ditemukan }\end{array}$ \\
\hline Peng & $\begin{array}{l}\text { Tampil notifikasi, } Q R \text { code } \\
\text { tidak sesuai, cerita tidak } \\
\text { ditemukan }\end{array}$ \\
\hline Hasil & Sesuai \\
\hline
\end{tabular}

\subsubsection{System Usability Testing}

Usability testing adalah salah satu metode yang digunakan untuk melihat tingkat kemudahan pengguna dalam berinteraksi dengan sebuah sistem informasi [11]. Pengujian System Usability dilakukan dengan memberikan kuesioner kepada beberapa calon konsumen startup Way'K untuk mengetahui efektifitas kegunaan sistem yang dibuat, tabel kuesioner dapat dilihat pada tabel 4.3.

Tabel 3. Daftar pernyataan System Usability Test

\begin{tabular}{|c|c|c|c|c|c|c|}
\hline No & $\begin{array}{c}\text { Daftar } \\
\text { Pernyataan } \\
\text { Skala }\end{array}$ & & Per & ilai & & \\
\hline 1 & Secara & & & & & \\
\hline & $\begin{array}{l}\text { keseluruhan } \\
\text { aplikasi mudah } \\
\text { digunakan }\end{array}$ & 1 & 2 & 3 & 4 & 5 \\
\hline 2 & $\begin{array}{l}\text { Fungsi aplikasi } \\
\text { sudah sesuai } \\
\text { dengan harapan }\end{array}$ & 1 & 2 & 3 & 4 & 5 \\
\hline 3 & $\begin{array}{l}\text { Aplikasi sudah } \\
\text { User Friendly, }\end{array}$ & 1 & 2 & 3 & t & 5 \\
\hline
\end{tabular}


pengguna tidak

kesulitan dalam

mengoperasikan

4 Aplikasi berjalan

dengan baik pada

smartphone

$\begin{array}{lllll}1 & 2 & 3 & 4 & 5\end{array}$

Android

5 Proses promosi

lebih menarik

dengan

menggunakan

aplikasi lukisan

Wayang Kamasan

6 Pengguna lebih

mudah

mengetahui cerita

dari lukisan

Wayang Kamasan

$\begin{array}{lllll}1 & 2 & 3 & 4 & 5\end{array}$

melalui aplikasi

menggunakan

metode scan $Q R$

7 Pengguna lebih

mudah

memperoleh

informasi

mengenai produk

lukisan Wayang

Kamasan dari

startup Way'K

Kuesioner diberikan kepada 10 responden yang terdiri dari wisatawan dan masyarakat hasil dari kuesioner dapat dilihat pada gambar 4.8.

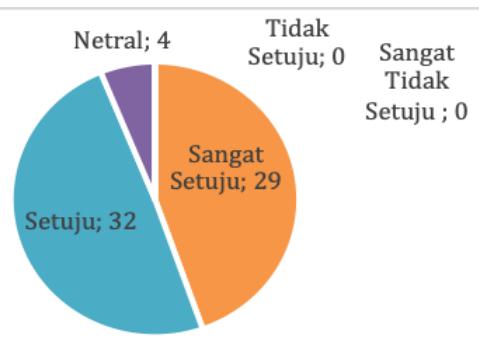

Gambar 12. Hasil Kuesioner Usability Testing

Setelah didapatkan nilai dari kuesioner maka selanjutnya dilakukan perhitungan skala likert. Yaitu sebuah metode skala bipolar yang mengukur baik tanggapan positif ataupun negatif terhadap suatu pernyataan [11] dalam hal ini adalah pernyataan mengenai kuesioner penilain aplikasi lukisan Wayang Kamasan. Perhitungan menggunakan bobot skala lekert yang dapat dilihat pada tabel 4.5.

Tabel 4. Bobot Skala Likert

\begin{tabular}{lc}
\hline \multicolumn{1}{c}{ Kategori Jawaban } & Bobot Nilai \\
\hline Sangat Setuju & 5 \\
Setuju & 4 \\
Netral & 3 \\
Tidak Setuju & 2 \\
Sangat Tidak Setuju & 1 \\
\hline
\end{tabular}

Hasil akhir skala likert dihitung dengan cara mengalikan total setiap kategori jawaban dengan bobot nilainya. Hasil perhitungan kuesioner menggunakan bobot nilai skala likert [12] dapat dilihat pada tabel 4.6.

Tabel 5 . Hasil Perhitungan Kuesioner Menggunakan Bobot Nilai Skala Likert

\begin{tabular}{lccc}
\hline $\begin{array}{l}\text { Kategori } \\
\text { Jawaban }\end{array}$ & $\begin{array}{c}\text { Jumlah } \\
\text { Total }\end{array}$ & Bobot & $\begin{array}{c}\text { Total } \\
\text { Nilai }\end{array}$ \\
\hline Sangat Setuju & 29 & 5 & 145 \\
Setuju & 32 & 4 & 128 \\
Netral & 4 & 3 & 12 \\
Tidak Setuju & 0 & 2 & 0 \\
Sangat Tidak & 0 & 1 & 0 \\
Setuju & & & \\
\hline Total & & & 285 \\
\hline
\end{tabular}

Untuk mengetahui persentase kepuasan terhadap sistem yang dibuat, pada penelitian ini digunakan rumus $\%$ kepuasan, dihitung dengan cara membagi total nilai dengan Y x 100, dengan $\mathrm{Y}=5 \mathrm{x}$ total responden $\mathrm{x}$ total pernyataan. Hasilnya adalah total responden $=10$ dan total pernyataan $=7$ maka :

$\mathrm{Y}=5 \times 10 \times 7$

$\mathrm{Y}=350$

$\%$ kepuasan $=$ total nilai $/ \mathrm{Y} \times 100$

$\%$ kepuasan $=285 / 350 \times 100$

$\%$ kepuasan $=81,43 \%$

Setelah didapat nilai dari tingkat kepuasan selanjutnya hal yang dilakukan adalah mencocokan nilai perhitungan skala likert dengan tabel persentase pada skala likert [12] yang dapat dilihat pada tabel 4.7. 
Tabel 6. Tabel Persentase Kategori Nilai Skala

Likert

\begin{tabular}{cc}
\hline \% Kepuasan & Keterangan \\
\hline $0 \%-19,99 \%$ & Sangat Buruk \\
$20 \%-39,99 \%$ & Buruk \\
$40 \%-59,99 \%$ & Cukup \\
$60 \%-79,99 \%$ & Baik \\
$80 \%-100 \%$ & Sangat Baik \\
\hline
\end{tabular}

Dari hasil perhitungan skala likert didapat nilai akhir 81,43 \% dan kemudian dicocokan dengan tabel persentase pada tabel 4.7. dan didapat hasil Sangat Baik.

\section{PENUTUP}

Hasil dari penelitian ini adalah hasil yang telah diperoleh menggunakan metode penelitian yang digunakan dan dapat disimpulkan sebagai berikut :

1. Aplikasi lukisan Wayang Kamasan telah berhasil dibuat dengan pemodelan use case diagram dan class diagram serta sistem dibangun dengan menggunakan framework Laravel pada bagian web admin dan framework React Native pada bagian aplikasi Android.

2. Pada penelitian ini menghasilkan satu aplikasi Android dan dan satu website dimana website diperuntukan untuk admin untuk menambah, mengubah dan menghapus data dari lukisan Wayang Kamasan dari startup Way'K dan aplikasi Android digunakan konsumen untuk mengetahui cerita dari lukisan wayang kamasan dengan cara scan $Q R$ yang ada pada lukisan serta untuk mengetahui informasi mengenai produk Way'K dan informasi seputar startup Way'K.

3. Pengujian menggunakan blackbox testing mendapatkan hasil bahwa fungsional dari aplikasi sudah berjalan sesuai harapan. Dan hasil pengujian dari usability testing mendapatkan hasil sangat baik.

\section{DAFTAR PUSTAKA}

[1] Badan Pusat Statistik Provinsi Bali,
"Kunjungan Wisatawan Asing Ke Bali," [Online]. Available: https://bali.bps.go.id/statictable/2018/02/ 09/28/jumlah-wisatawan-asing-ke-balidan-indonesia-1969-2017.html. [Accessed 5 Maret 2018].

[2] I. G. B. R. Utama and N. M. E. Mahadewi, "Faktor Penentu Wisatawan Eropa Memilih Bali Sebagai Destinasi Pariwisata," Jurnal Kepariwisataan, vol. 15, no. 2, p. 9, 2015.

[3] I. W. Mudana, "Transformasi Seni Lukis Wayang Kamasan Pada Era Postmodern di Klungkung Bali," Program Pasca Sarjana Universitas Udayana, Denpasar, 2015.

[4] B. Sugiantoro and F. Hasan, "Pengembangan QR Code Scanner Berbasis Android Untuk Sistem Informasi Museum Sonobudoyo Yogyakarta," Telematika, vol. 12, no. 2, p. 145, 2015.

[5] A. Wijaya and A. Gunawan, "Penggunaan QR Code Sarana Penyampaian Promosi Dan Informasi Kebun Binatang Berbasis Android," Bianglala Informatika, vol. 4, no. 1, p. 20, 2016.

[6] T. Cata, S. Payal, Petel and T. Sakaguchi, "QR Code: A New Opportunity for Effective Mobile Marketing," Journal of Mobile Technologies, Knowledge and Society, vol. 2013, p. 1, 2013.

[7] K. H. Pandya and H. J. Galiyawala, "A Survey on QR Codes: in context of Research and Application," International Journal of Emerging Technology and Advanced Engineering, vol. 4, no. 3, p. 258, 2014.

[8] R. Das and L. P. Saikia, "Comparison of Procedural PHP with Codeigniter and Laravel Framework," International Journal of Current Trends in Engineering \& Research (IJCTER), vol. 2, no. 6, p. 47, 2016.

[9] W. Danielsson, "React Native application development," Linköpings universitet, Swedia, 2016. 
[10] R. S. Pressman, Software Engineering A Practitioner's Approach, New York City: McGraw-Hill, 2010.

[11] Henriyadi and R. Mulyani, "Usability Testing Sistem Informasi: Studi Kasus Pada Aplikasi Repositori Publikasi Badan Penelitian Dan Pengembangan Pertanian," Pusat Perpustakaan dan Penyebaran Teknologi Pertanian, Bogor, 2014.

[12] Maryuliana, I. M. I. Subroto and F. C. S. Haviana, "Sistem Informasi Angket Pengukuran Skala Kebutuhan Materi Pembelajaran Tambahan Sebagai Pendukung Pengambilan Keputusan Di Sekolah Menengah Atas Menggunakan Skala Likert," Jurnal Transistor Elektro dan Informatika, vol. 1, no. 2, p. 4, 2016. 